\title{
An Eocene land snail Balticopta gusakovi gen.n., sp.n. (Stylommatophora: Gastrocoptidae) from Baltic amber
}

\author{
I.A. Balashov ${ }^{1}$, E.E. Perkovsky ${ }^{1,2}$ \\ ${ }^{1}$ I.I. Schmalhausen Institute of Zoology, B. Khmelnitsky str., 15, Kiev, 01030, Ukraine. \\ 2 A.A. Borissiak Paleontological Institute, Russian Academy of Sciences, Profsoyuznaya 123, \\ Moscow, 117868 Russia. \\ E-mails: igor_balashov@ukr.net,perkovsk@gmail.com
}

ABSTRACT: We describe a monotypic genus from Priabonian (late Eocene) Baltic amber that has a moderately small $(1.3 \times 2.1 \mathrm{~mm})$, ovate-conic shell with a large free aperture extended to the wall of the penultimate whorl. The parietal margin of the aperture is reflected and has a lip. The aperture is only partially visible because of dirt and an air bubble in the amber. At least one simple angular lamella is present relatively deep in the aperture.

How to cite this article: Balashov I.A., Perkovsky E.E. 2020. An Eocene land snail Balticopta gusakovi gen.n., sp.n. (Stylommatophora: Gastrocoptidae) from Baltic amber // Invert. Zool. Vol.17. No.1. P.18-24. doi: 10.15298/invertzool.17.1.02

KEY WORDS: Mollusca, Gastropoda, Pupilloidea, terrestrial molluscs, Priabonian, fossil.

\section{Эоценовая улитка Balticopta gusakovi gen.n., sp.n. (Stylommatophora: Gastrocoptidae) из балтийского янтаря}

\author{
И.А. Балашов ${ }^{1}$, Е.Э. Перковский ${ }^{1,2}$ \\ ${ }^{1}$ Институт зоологии им. И. И. Шмальгаузена НАН Украины, ул. Б. Хмельницкого, 15, Киев, \\ 01030, Украина. \\ E-mails: igor_balashov@ukr.net,perkovsk@gmail.com
}

РЕЗЮМЕ: Описанный новый монотипический род из приабонского (поздний эоцен) балтийского янтаря имеет относительно небольшую (1,3×2,1 мм) овально-коническую раковину с большим свободным устьем, удлиненным на стенку предпоследнего оборота. Париетальный край устья отвернут и имеет губу. Устье только частично видимо в связи с грязью и пузырьком воздуха в янтаре. Имеется, по меньшей мере, один простой ангулярный ламеллярный зуб относительно глубоко в устье.

Как цитировать эту статью: Balashov I.A., Perkovsky E.E. 2020. An Eocene land snail Balticopta gusakovi gen.n., sp.n. (Stylommatophora: Gastrocoptidae) from Baltic amber // Invert. Zool. Vol.17. No.1. P.18-24. doi: 10.15298/invertzool.17.1.02

КЛЮЧЕВЫЕ СЛОВА: Mollusca, Gastropoda, Pupilloidea, наземные моллюски, приабонский. 


\section{Introduction}

Terrestrial molluscs are one of the most speciose groups of organisms after insects and apparently have had a similar proportion of species since the Cretaceous (Cameron, 2016). Although molluscs, in contrast to insects, are very rare in amber. Several snails are known from Cretaceous Lebanese and Burmese amber, but only two species are described (Roth et al., 1996; Yu et al., 2018; Xing et al., 2019). Only a few gastropods were reported from Miocene Dominican amber, without species identification (Poinar, Roth, 1991; Penney, 2010), and ten snail species have been described from late Eocene Baltic amber, while only about 20 amber-embedded snail specimens have been mentioned in publications (Klebs, 1886; Sandberger, 1887; Stworzewicz, Pokryszko, 2006, 2015). At the same time, at least 3500 arthropod species are known from Baltic amber (Penney, Preziosi, 2014).

The age of Baltic amber was disputed for a long time (e.g., see discussion in Perkovsky et al., 2007), but the Priabonian (late Eocene) dating of the amberiferous Prussian Formation is strongly supported by available paleontological data (Aleksandrova, Zaporozhets, 2008). Extant Holarctic taxa dominate Baltic amber fauna (Dlussky, Rasnitsyn, 2009; Perkovsky, 2016, 2017; Staniczek et al., 2017); this corresponds well to the Priabonian climate in RussoScandia. Thermophilic animals and plants associated with an extant tropical climate are numerous in Ypresian (early Eocene) Oise amber, Ypresian and Lutetian (middle Eocene) compession fossils of Northern and Middle Europe but are much rarer than the aforementioned Holarctic taxa in Baltic amber and its coeval Rovno, Danish and Bitterfeld ambers (Szwedo, 2011; Szwedo, Wappler, 2006; Ivanov et al., 2016; Sokolloff et al., 2018 and references therein).

\section{Material and methods}

The holotype was collected in Yantarnyi (Kaliningrad region, Russia) in 2011 and has been stored in V. Gusakov's private collection.
Currently, it is housed in the amber collection of the I.I. Schmalhausen Institute of Zoology, Kiev (SIZK). Syninclusions from the sample have been removed.

Systematics of the family level and higher follow Bouchet et al. (2017), except that we believe Orthurethra Pilsbry, 1900 should be considered a suborder instead of an infraorder, and the latter name is more suitable than Pupilloidei Schileyko, 1979 (see discussion in Balashov, 2016).

Common terminology for aperture description in Gastrocoptidae is used (e.g. Pilsbry, 1916-1918; Schileyko, 1998). The term "complete aperture" indicates a continuous peristome: an aperture with all margins, including a parietal margin that can be absent if the walls of the aperture are connected directly to the wall of the penultimate whorl. The term "free aperture" indicates a continuous detached peristome: an aperture with margins that are not connected to the wall of the penultimate whorl.

\section{Systematics}

Class Gastropoda Cuvier, 1797

Subclass Heterobranchia Gray, 1840

Superorder Eupulmonata Haszprunar et $\mathrm{Hu}-$ ber, 1990

Order Stylommatophora Schmidt, 1855

Suborder Orthurethra Pilsbry, 1900

Superfamily Pupilloidea Turton, 1831

Family Gastrocoptidae Pilsbry, 1918

\section{Genus Balticopta gen.n.}

Type species: Balticopta gusakovi sp.n.

Diagnosis: Shell ovate-conic, with large free aperture extended to the wall of penultimate whorl. Parietal margin of aperture reflected, with lip. Angular lamella simple, small, not bifurcate, located relatively deep in aperture. Umbilicus small, droplet-shaped.

Monotypic genus.

Etymology: Arbitrary combination of letters, -copta from the ending of "Gastrocopta", the type genus of the family, and "Baltic", after its occurrence in Baltic amber. Feminine. 

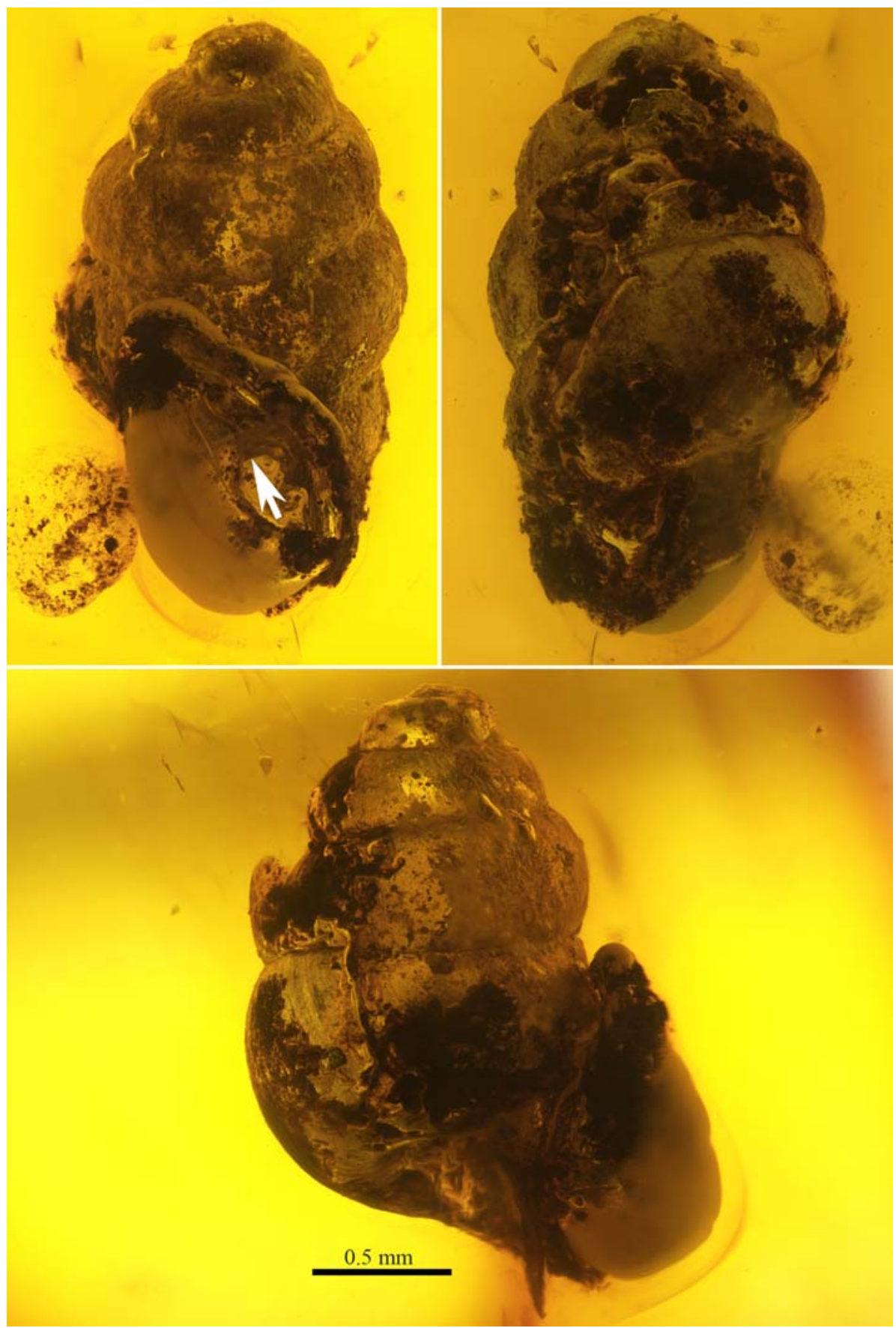

Fig. 1. Holotype of Balticopta gusakovi sp.n. in amber from three angles. Angular lamella is marked by arrow.

Рис. 1. Голотип Balticopta gusakovi sp.n. в янтаре с трех ракурсов. Ангулярная пластинка отмечена стрелкой. 


\section{Balticopta gusakovi sp.n. Fig. 1.}

Holotype: SIZK B-13 (original number in Gusakov's collection CVGM No. 2MGP2011). The piece of amber is shaped similar to a triangular prism with side lengths of $10 \mathrm{~mm}, 9 \mathrm{~mm}$ and $7 \mathrm{~mm}$, containing a single shell only.

Syninclusions: Diplopoda; Acari; two Diptera, Sciaridae and Cecidomyiidae (Ledomyia sp.) (CVGM, N 2 GP2011).

Description: Shell dextral, ovate-conic, with 4.5 moderately convex whorls. Coloration does not differ from surrounding amber. Shell surface almost smooth; very weak irregular striation visible on some whorls. Height of body whorl about half of shell's height. Aperture free, complete, unusually large and extended to the wall of penultimate whorl forming sinulus in left upper corner (although partial deformation is possible), located relatively far forward from the body whorl; consequently, last whorl before aperture relatively elongated forming small curve (partly observable from palatal side, but unavailable for imaging because of the angle to the amber's surface from this side). Margins of aperture with lip and reflected, including parietal margin. Inner aperture not easily observable due to dirt and air bubble in amber, inner columellar and basal walls are completely obscured. At least one angular lamellate tooth is present (partly visible among dirt on fig. 1, marked by arrow). It is simple, small, not bifurcate, located relatively deep in aperture, extended further inside shell (its end inside shell is obscured). Tooth-like structure appears to be present on upper part of palatal wall, but we can't rule out that this is dirt (visible on fig. 1, right from arrow). Other teeth may be present but unobservable. Umbilicus open, dropletshaped, small, about $0.1 \mathrm{~mm}$ width.

Size: Width $1.3 \mathrm{~mm}$, height $2.1 \mathrm{~mm}$, body whorl's and aperture's height $1.1 \mathrm{~mm}$, height of visible part of first whorl $0.2 \mathrm{~mm}$, second whorl $0.3 \mathrm{~mm}$, third whorl $-0.5 \mathrm{~mm}$.

Type locality: Yantarnyi (Kaliningrad region, Russia).

Age: Priabonian (late Eocene).
Etymology: The species is named after Viktor A. Gusakov (Zvyozdny gorodok, Moscow region, Russia), who kindly provided the amber piece containing the newly described species.

\section{Discussion}

Klebs (1886) described two Vertigo species from Baltic amber, but both are much smaller (shell widths $0.8 \mathrm{~mm}$ and $1.0 \mathrm{~mm}$ ) than the new species. Thus, they cannot be subadults of the newly described snail. The vertiginid Propupa hoffeinsorum Stworzewicz et Pokryszko, 2006 very different from the new species in shape (Stworzewicz, Pokryszko, 2006). The recently described Ptychalaea mystica Stworzewicz et Pokryszko, 2015 differs from the new species by the incomplete aperture and extremely different apertural dentition (Stworzewicz, Pokryszko, 2015).

One of the most notable features of the new species is its unusual aperture shape. However, the shell is damaged, and it is unclear how exactly the aperture was naturally constructed. The parietal margin of the aperture may be displaced because of damage, but there are no visible deformations on the parietal and palatal margins. This lack of visible deformation provides evidence that the aperture margins are placed at a more or less natural position. Even when deformation is considered, there are no other known species with a reflexed parietal margin of the aperture developed to this degree among similarly shaped genera of Vertiginidae, Gastrocoptidae or any other taxa (Pilsbry, 19161918, 1920-1921, 1922-1926; Pilsbry, Cooke, 1918-1920; Wenz, Zilch, 1959-1960; Gozhik, Prisyazhnyuk, 1978; Schileyko, 1998; Harzhauser et al., 2014a, b; Harzhauser, Neubauer, 2018; Nekola et al., 2018). In the new species, the aperture is elongated and relatively forward from the body whorl ("free aperture"), forming a well-developed parietal margin.

The new species is similar to some Vertiginidae species in general appearance and by the relatively deeply placed simple angular lamella. Few Vertigo species are known from the Eocene of Europe (Nordsieck, 2014). However, the 
shell of our species is more conical than that of Vertiginidae species and appears to be colorless (the color of the shell does not differ from the color of the amber), which does not occur in Vertiginidae. Furthermore, the large, free aperture extended to the wall of the penultimate whorl is never found in Vertiginidae. The free aperture is characteristic of many Gastrocoptidae (including Hypselostomatinae Zilch, 1959), most notably Bensonella Pilsbry et Vanatta, 1900, Boysidia Ancey, 1881, Gyliotrachela Tomlin, 1930, Cavipupa Pilsbry, 1934 and Chaenaxis Pilsbry et Ferris, 1906 (Pilsbry, 1916-1918; Pilsbry, Cooke, 1918-1920; Wenz, Zilch, 1959-1960; Schileyko, 1998). A nearly free, large aperture elongated to the penultimate whorl, similar to that of the new species, is known in several Gastrocopta Wollaston, 1878 species; however, the parietal margin is much weaker in the Gastrocopta species (Gozhik, Prisyazhnyuk, 1978; Stworzewicz, Prisyazhnyuk, 2006; Harzhauser et al., 2014a, b; Harzhauser, Neubauer, 2018). A relatively similar complete aperture also occurs in some Ptychalaea Boettger, 1889 (Gastrocoptidae) species, most notably in $P$. flexidens (Reuss, 1861) from the Miocene (Harzhauser et al., 2014a), but its aperture is much smaller. Mentioned Gastrocopta and Ptychalaea are known from Eocene of Europe (Nordsieck, 2014).

Given the evidence, the free aperture and the ovate-conical likely colourless shell strongly suggest that the new species is representative of Gastrocoptidae, not Vertiginidae or any other family.

Below we present evidence suggesting that the new genus differs from all others in Gastrocoptidae. Bensonella, Boysidia, Gyliotrachela and a few other similar genera that were placed in the Hypselostomatinae (not used in recent classification) strongly differ from Balticopta in the very conical shell with the wide umbilicus, as well as the much more prominent, different apertural dentition. Therefore, the new species is similar to the aforementioned genera due to the aperture position but differs in all other characters.

Extant Cavipupa from Philippines and Chaenaxis from North America are similar in the shell shape and size of Balticopta, although the shell of Cavipupa is much more conical, and the shell of Chaenaxis is much more cylindrical. Both Cavipupa and Chaenaxis have a wide umbilicus and large angular lamella on the edge of the aperture (Schileyko, 1998), strongly differing from Balticopta.

As previously mentioned above, Balticopa differ from Gastrocopta in the much weaker and not reflected parietal margin of aperture despite a similar appearance. Additionally, in Gastrocopta the angular lamella is on the edge of the aperture and usually large and bifurcate.

In Ptychalaea the aperture is smaller than that of Balticopta and never extends to the wall of the penultimate whorl. It also has a very large angular lamella on the edge of the aperture. There are problems in the taxonomy of this genus. The type species of Ptychalaea is $P$. flexidens (Reuss, 1861) from the Miocene of Europe. Pilsbry and Cooke (1918-1920) have placed the extant Nesopupa dedecora Pilsbry, 1902 from Japan with its geographical form "Nesopupa tamagonari Pilsbry, Hirase, 1904" in Ptychalaea. They did not examine the type of $P$. flexidens, only referring to illustrations (Pilsbry, Cooke, 1918-1920). Apparently, N. dedecora and P. flexidens were never compared. Nekola and Coles (2016) have shown that "Ptychalaea tamagonori" [sic] is a species of Vertigo. Later Nekola et al. (2018) synonymized Ptychalaea with Vertigo and placed in it $V$. dedecora with its synonym $V$. tamagonari. However, from the photo of $P$. flexidens in Harzhauser et al. (2014a, Fig. 8, E) it is clear that $P$. flexidens is very different from the Japanese snails in apertural dentition (see Fig. 13 in Nekola et al., 2018), most notably in the position of the angular lamella. Harzhauser et al. (2014a) suggested Ptychalaea should be placed in Gastrocoptidae based on the morphology of the angularis. We agree and follow the suggestion here. Therefore, $V$. dedecora is not a species of Ptychalaea, and there should be no consequence for the taxonomic status of Ptychalaea in this regard.

Given the above evidence, the new species greatly differs from all known genera of Gastro- 
coptidae and placing it in one of these genera would change the diagnosis and likely create polyphyletic taxa. Therefore, introducing a new genus is less disruptive to the systematics of Gastrocoptidae.

The introduction of new genera without molecular phylogenetic hypotheses, especially regarding land snails, has been disputed in the past. We follow the position of Páll-Gergely (2017) in this problem.

The distribution of Gastrocoptidae and Gastrocopta is nearly worldwide, while other attributed genera are scattered around the world (Pilsbry, 1916-1918; Pilsbry, Cooke, 1918-1920; Wenz, Zilch, 1959-1960; Schileyko, 1998). Currently Gastrocoptidae is rare in Europe, but in the Miocene deposits of Europe, it is one the most common groups of terrestrial molluscs (Wenz, Zilch, 1959-1960; Gozhik, Prisyazhnyuk, 1978; Harzhauser et al., 2014a, b; Harzhauser, Neubauer, 2018). In contrast to Europe, many species of Gastrocoptidae remain extant in North America and Asia (Schileyko, 1998). Therefore, distributional data from extant species correspond to the Holarctic distribution of most taxa known from Baltic amber.

Acknowledgments. We are very grateful to V.A. Gusakov (Zvyozdny gorodok, Moscow region) for providing amber specimens for study, to A.P. Vlaskin (SIZK) for cutting and polishing it, to E.V. Martynova (SIZK) for help with photos and for correcting English in the manuscript of this paper, to Z.A. Fedotova (All-Russia Research Institute of Plant Protection, Saint-Petersburg - Pushkin) for determination of gall midge, to Sarah C. Crews (California Academy of Sciences) for correcting English and to reviewers and editors who improved the manuscript.

\section{References}

Aleksandrova G.N., Zaporozhets N.I. 2008. Palynological characteristics of Upper Cretaceous and Paleogene deposits on the West of the Sambian Peninsula (Kaliningrad region), Part 2 // Stratigraphy and Geological Correlation. Vol.16. No.5. P.528-539.

Balashov I.A. 2016. [Fauna of Ukraine. Vol.29: Molluscs. Issue 5: Stylommatophorans (Stylommatophora)]. Kiev: Naukova Dumka. 592 p. [In Russian, with English summary]
Bouchet P., Rocroi J.P., Hausdorf B., Kaim A., Kano Y., Nützel A., Parkhaev P., Schrödl M., Strong E.E. 2017. Revised classification, nomenclator and typification of gastropod and monoplacophoran families // Malacologia. Vol.61. No.1-2. P.1-526.

Cameron R. 2016. Slugs and snails. William Collins. London. 510 p.

Dlussky G.M., Rasnitsyn A.P. 2009 Ants (Insecta: Vespida: Formicidae) in the Upper Eocene amber of Europe // Paleontological Journal. Vol.43. No.9. P.10241042.

Gozhik P.F., Prisyazhnyuk V.A. 1978. [Freshwater and terrestrial molluscs of Miocene of right-bank Ukraine]. Kiev: Naukova Dumka. 172 pp. [In Russian]

Harzhauser M., Neubauer T.A. 2018, Opole (Poland) - a key locality for middle Miocene terrestrial mollusc faunas // Bulletin of Geosciences. Vol.93. No.1. P.71146.

Harzhauser M., Neubauer T.A., Georgopoulou E., Harl J. 2014a. The Early Miocene (Burdigalian) mollusc fauna of the North Bohemian Lake (Most Basin) // Bulletin of Geosciences. Vol.89. No.4. P.819-908.

Harzhauser M., Neubauer T.A., Gross M., Binder H. 2014b. The early Middle Miocene mollusc fauna of Lake Rein (Eastern Alps, Austria) // Palaeontographica A (Paleozoology, Stratigraphy). Vol.302. No.1-6. P.1-71.

Ivanov V.D., Melnitsky S.I., Perkovsky E.E. 2016. Caddisflies from Cenozoic resins of Europe // Paleontological Journal. Vol.50. No.5. P.485-493.

Klebs R. 1886 [“1885"]. Gastropoden im Bernstein // Jahrbuch der Königlich Preussischen Geologischen Landesanstalt und Bergakademie Berlin für das Jahr. Bd.6. S.366-394.

Nekola J.C., Coles B.F. 2016. Supraspecific taxonomy in the Vertiginidae (Gastropoda, Stylommatophora) // Journal of Molluscan Studies. Vol.82. No.1. P.208212.

Nekola J. C., Chiba S., Coles B.F., Drost C.A., Proschwitz T.V., Horsák M. 2018. A phylogenetic overview of the genus Vertigo O.F. Müller, 1773 (Gastropoda: Pulmonata: Pupillidae: Vertigininae)// Malacologia. Vol.62. No.1. P.21-161.

Nordsieck H. 2014. Annotated check-list of the genera of fossil land snails (Gastropoda: Stylommatophora) of western and central Europe (Cretaceous-Pliocene), with description of new taxa // Archiv für Molluskenkunde. Vol.143. No.2. P.153-185.

Páll-Gergely B. 2017. Should we describe genera without molecular phylogenies? // Zootaxa. Vol.4232. No.4. P.593-596.

Penney D. 2010. Dominican amber // D. Penney (ed.). Biodiversity of fossils in amber from the major world deposits. Manchester: Siri Scientific Press. P.22-41.

Penney D., Preziosi R.F. 2014. Estimating fossil ant species richness in Eocene Baltic amber // Acta Palaeontologica Polonica. Vol.59. P.927-929.

Perkovsky E.E. 2016. Tropical and Holarctic ants in Late Eocene Ambers // Vestnik zoologii. Vol.50. No.2. P.111-122. 
Perkovsky E.E. 2017. Comparison of biting midges of the Early Eocene Cambay amber (India) and Late Eocene European ambers supports the independent origin of European ambers // Vestnik zoologii. Vol.51. No.4. P.275-284.

Perkovsky E.E., Rasnitsyn A.P., Vlaskin A.P., Taraschuk M.V. 2007. A comparative analysis of the Baltic and Rovno amber arthropod faunas: representative samples // African Invertebrates. Vol.48. No.1. P.229245.

Pilsbry H.A. 1916-1918. Manual of Conchology. Second Series: Pulmonata, 24. Pupillidae (Gastrocoptinae). Philadelphia: Academy of Natural Sciences of Philadelphia. 380 p.

Pilsbry H.A. 1920-1921. Manual of Conchology. Second Series: Pulmonata, 26. Pupillidae (Vertigininae, $\mathrm{Pu}$ pillinae). Philadelphia: Academy of Natural Sciences of Philadelphia. $254 \mathrm{p}$.

Pilsbry H.A. 1922-1926. Manual of Conchology. Second Series: Pulmonata, 27. Pupillidae (Orculinae, Pagodulinae, Acanthinulinae, etc). Philadelphia: Academy of Natural Sciences of Philadelphia. 369 p.

Pilsbry H.A., Cooke C.M. 1918-1920. Manual of Conchology. Second Series: Pulmonata, 25. Pupillidae (Gastrocoptinae, Vertigininae). Academy of Natural Sciences of Philadelphia. Philadelphia. 401 pp.

Poinar G.O., Roth B. 1991. Terrestrial snails (Gastropoda) in Dominican amber // Veliger. Vol.34. P.253-258.

Roth B., Poinar G.O., Acra A., Acra F. 1996. Probable pupillid land snail of Early Cretaceous (Hauterivian) age in amber from Lebanon // Veliger. Vol.39. P.8788 .

Sandberger F. 1887. Bemerkungen über einige Heliceen im Bernstein der preussischen Küste // Schriften der Naturforschenden Gesellschaft in Danzig, N.F. Bd.6. H.4. S.137-141.

Schileyko A.A. 1998. Treatise on Recent Terrestrial Pulmonate Molluscs. Part 2: Gastrocoptidae, Hypselostomatidae, Vertiginidae, Truncatellinidae, Pachnodidae, Enidae, Sagdidae // Ruthenica. Suppl.2. P.129-261.
Sokoloff D.D., Ignatov M.S., Remizowa M.V., Nuraliev M.S., Blagoderov V., Garbout A., Perkovsky E.E. 2018. A male flower of Prunus s.l. (Rosaceae) from Eocene Rovno amber (Ukraine) // Journal of Plant Research. Vol.131. No.6. P.925-943.

Staniczek A.H., Godunko R.J., Kluge N.J. 2017. Fossil record of the mayfly family Ephemerellidae (Insecta: Ephemeroptera), with description of new species and first report of Ephemerellinae from Baltic amber // Journal of Systematic Palaeontology. Vol.16. No.15. P.1319-1335.

Stworzewicz E., Pokryszko B.M. 2006. Eocene terrestrial snails (Gastropoda) from Baltic amber // Annales Zoologici. Vol.56. No.1. P.215-224.

Stworzewicz E., Pokryszko B.M. 2015. A new pupilloid species and some other Eocene terrestrial gastropods from Baltic amber // Palaeontographica, Abteilung A. Vol.304. P.65-75.

Stworzewicz E., Prisyazhnyuk V.A. 2006. A new species of Miocene terrestrial gastropod Gastrocopta from Poland and the validity of "Pupa (Vertigo) suevica" // Acta Palaeontologica Polonica. Vol.51. No.1. P.165170 .

Szwedo J. 2011. Ordralfabetix sirophatanis gen. et sp. n. - the first Lophopidae from the Lowermost Eocene Oise amber, Paris Basin, France (Hemiptera: Fulgoromorpha) // Zootaxa. Vol.2822. P.52-60.

Szwedo J., Wappler T. 2006. New planthoppers (Insecta: Hemiptera: Fulgoromorpha) from the Middle Eocene Messel Maar // Annales Zoologici. Vol.56. No.3. P.555-566.

Yu T., Wang B., Pan H. 2018. New terrestrial gastropods from mid-Cretaceous Burmese amber // Cretaceous Research. Vol.90. P.254-258.

Wenz W., Zilch A. 1959-1960. Gastropoda. Teil 2. Euthyneura. Berlin: Borntraeger. $834 \mathrm{~S}$.

Xing L., Ross A.J., Stilwell J.D., Fang, J., McKellar R.C. 2019. Juvenile snail with preserved soft tissue in midCretaceous amber from Myanmar suggests a cyclophoroidean (Gastropoda) ancestry // Cretaceous Research. Vol.93. P.114-119.

Responsible editor A.Yu. Zhuravlev 